\title{
MENINGKATKAN MOTIVASI DAN KETRAMPILAN PROSES SAINS MELALUI KERJA ILMIAH BERTANYA PADA KONSEP SISTEM KLASIFIKASI TUMBUHAN DALAM PENERAPAN KURIKULUM 2013 DI SISWA SMP KELAS VII AMBON
}

\author{
Pamella Mercy Papilaya \\ Dosen Program Studi Pendidikan Biologi FKIP Unpatti \\ E-mail: pm_papilaya@yahoo.com
}

\begin{abstract}
Background: The concept of classification of living things, especially the determination key materials, is one of the concepts in learning biology is quite difficult to understand by students. The concept of learning in the classroom tend to use traditional approaches in the form of lectures and experiments. Questioning skills very important to have a teacher, because it can increase student participation in the learning activity, generate interest and curiosity, develop ways of thinking and active learning, and focus on students.

Methods: This study was conducted using the draft Action Research (PTK) is carried out in collaboration with the seventh grade biology teacher and vice principal at Junior High School Curriculum affairs 6 Ambon. PTK is held in the classroom while the class VII1 VII2 used as a test model of learning.

Results: The results showed that apply the concepts and principles in biology through scientific work asked to improve the performance of teachers. Application of scientific work asks improve student learning outcomes. Application of scientific work asks improve student motivation. Application of scientific work asked to create a climate conducive learning and Application of scientific work asks improve students' science process skills.

Conclusions: The implementation of learning in the classroom that teachers must practice more to phrase questions to reveal the facts, prepare questions about the procedure, prepare questions about the reasons for the use of certain tools or materials and prepare questions for designing a scientific activity.
\end{abstract}

Keywords: Concepts and Principles Within Life Sciences, Scientific Work inquiry, Science Process Skills.

\section{Abstrak}

Latar Belakang: Konsep klasifikasi mahkluk hidup, khususnya materi kunci determinasi, merupakan salah satu konsep dalam pembelajaran Biologi yang cukup sulit dipahami oleh siswa. Pembelajaran konsep ini di kelas cenderung menggunakan pendekatan tradisional berupa ceramah dan eksperimen. Keterampilan bertanya sangat penting dimiliki seorang guru, karena dapat meningkatkan partisipasi siswa dalam kegitan pembelajaran, membangkitkan minat dan rasa ingin tahu, mengembangkan pola berpikir dan cara belajar aktif, dan memusatkan perhatian siswa.

Metode: Penelitian ini dilaksanakan menggunakan rancangan Penelitian Tindakan Kelas (PTK) ini dilaksanakan secara kolaborasi dengan guru Biologi kelas VII dan wakil kepala sekolah urusan Kurikulum di SMP Negeri 6 Ambon. PTK ini dilaksanakan di kelas $\mathrm{VII}_{1}$ sedangkan kelas $\mathrm{VII}_{2}$ digunakan sebagai uji coba model pembelajaran.

Hasil: Hasil penelitian menunjukkan bahwa penerapkan konsep dan prinsip dalam biologi melalui kerja ilmiah bertanya dapat meningkatkan kinerja guru. Penerapan kerja ilmiah bertanya meningkatkan hasil belajar siswa. Penerapan kerja ilmiah bertanya meningkatkan motivasi belajar siswa. Penerapan kerja ilmiah bertanya menciptakan iklim belajar yang kondusif dan enerapan kerja ilmiah bertanya meningkatkan ketrampilan proses sains siswa.

Kesimpulan: Pelaksanaan pembelajaran di kelas yaitu guru harus lebih banyak berlatih menyusun pertanyaan untuk mengungkapkan fakta, menyusun pertanyaan tentang prosedur, menyusun pertanyaan tentang alasan penggunaan alat atau bahan tertentu dan menyusun pertanyaan untuk merancang suatu kegiatan ilmiah.

Kata Kunci: Konsep dan Prinsip Dalam Biologi, Kerja Ilmiah Bertanya, Ketrampilan Proses Sains. 


\section{PENDAHULUAN}

Pendidikan Biologi menekankan pada pemberian pengalaman secara langsung, karena siswa perlu dibantu dalam mengembangkan sejumlah ketrampilan proses supaya mereka mampu menjelajahi dan memahami alam sekitar (Depdiknas, 2003). Belajar merupakan suatu proses dan suatu kegiatan. Belajar yang baik bukan hanya mengingat tetapi lebih luas lagi yaitu mengalami. IPA adalah hal yang berkaitan dengan cara mencari tahu tentang alam secara sistematis sehingga IPA bukan hanya penguasaan kumpulan pengetahuan yang berupa fakta, konsep, atau prinsip saja, tetapi juga merupakan suatu proses penemuan (Trianto, 2007). Sejalan dengan itu hakikat pembelajaran IPA terdiri dari tiga komponen utama yaitu IPA sebagai produk, IPA sebagai proses, dan IPA sebagai sikap. Oleh karena itu, pembelajaran IPA menekankan pemberian pengalaman langsung kepada siswa agar siswa dapat memahami konsep yang dapat melekat lama ke dalam diri maupun ingatan siswa (Susanto, 2014).

Konsep Klasifikasi Mahkluk Hidup, khususnya materi Kunci Determinasi, merupakan salah satu konsep dalam pembelajaran Biologi yang cukup sulit dipahami oleh para siswa. Pembelajaran konsep ini di kelas cenderung menggunakan pendekatan tradisional berupa ceramah dan eksperimen. Cukup berhasil memang namun ada satu hal yang terlupakan dimana siswa dalam proses pembelajaran lebih cenderung menjadi pendengar yang baik dan guru merupakan satu-satunya Narasumber yang memberikan informasi. Dengan kata lain dapat dikatakan bahwa semua informasi yang diperoleh siswa bersal dari guru, sehingga nalar berpikir siswa kurang berkembang, siswa kurang diarahkan untuk mencari dan menemukan sendiri informasi.

Kesulitan siswa dalam mempelajari materi klasifikasi tumbuhan menuntut guru lebih kreatif dan inovatif dalam menyajikan materi sehingga dapat membantu pemahaman siswa terhadap materi ini. Kerangka berfikir dalam pembelajaran klasifikasi tumbuhan haruslah diajarkan kepada siswa, selama ini siswa hanya mengingat ciri-ciri dari tumbuhan kemudian mengklasifikasikannya tanpa memahami mengapa mereka harus mengetahui ciri dan tujuan pengklasifikasian pada tumbuhan. Dengan mengajarkan kerangka berfikir dengan menggunakan klasifikasi seperti dikemukakan oleh Rustaman (2005) bahwa ketika mempelajari sistematika tumbuhan tidak hanya mempelajari ciri yang dimiliki tumbuhan tersebut tetapi hubungan kekerabatan dalam sistematika tumbuhan, dengan demikian siswa sebagai generasi penerus dapat mengelola kekayaan hayati dengan baik dan benar.

Pembelajaran klasifikasi tumbuhan dengan metode ceramah saja dengan mengajarkan siswa untuk mengingat ciri kemudian mengkasifikasikan akan mengakibatkan mengalami beban kognitif. Siswa mengalami beban kognitif dikarenakan banyaknya istilah baru yang harus dipelajari kemudian siswa harus mengetahui ciri yang dimiliki tumbuhan dan kemudian mengklasifikasikan. Hal tersebut dikarenakan kapasitas memori siswa terbatas, siswa harus belajar tidak hanya biologi tetapi pelajaran lainnya selain itu tuntutan dari mata pelajaran yang lainnya juga cukup banyak. Istilah baru, mengetahui ciri dan tuntutan mata pelajaran lainnya mengakibatnya siswa memiliki beban kognitif tinggi atau memori kerja yang disimpan melebihi batas yang dimilikinya.

Pembelajaran klasifikasi tumbuhan atau mengelompokkan tumbuhan juga dapat mengakibatkan beban kognitif bagi para siswa karena memerlukan kemampuan yang kompleks yaitu konten dan konteksnya. Kontennya yaitu pengetahuan mengenai tumbuhan itu sendiri, sedangkan konteksnya adalah bagaimana tumbuhan ini dikelompokkan berdasarkan atas apakah persamaan ataukah perbedaannya. Dengan demikian siswa tidak hanya memahami tentang tumbuhannya tetapi juga tentang dasar pengelompokkan, siswa dapat melihat contoh-contoh yang di berikan oleh para ahli klasifikasi. Apabila salah satu bagian tersebut tidak diperhatikan contohnya kontennya maka pengkalsifikasian tidak dapat berjalan dengan baik akibatnya siswa mengalami beban kognitif dan melakukan usaha-usaha sehingga beban kognitifnya berkurang.

Menurut Syah (2010) prestasi belajar dipengaruhi oleh beberapa faktor yang dibedakan antara faktor internal dan faktor 
eksternal. Faktor internal meliputi faktor fisiologis dan psikologis siswa. Faktor fisiologis seperti penglihatan, pendengaran, struktur tubuh, dan sebagainya, sedangkan faktor psikologis seperti kecerdasan, sikap, bakat, minat, dan motivasi. Faktor eksternal terdiri atas dua macam yaitu faktor lingkungan sosial dan lingkungan seperti keluarga, guru dan staf, masyarakat, dan teman, sedangkan faktor lingkungan nonsosial seperti adat istiadat, ilmu pengetahuan, teknologi, kesenian, iklim, dan fasilitas belajar. Salah satu faktor internal yang mempengaruhi prestasi belajar siswa adalah motivasi belajar. Motivasi merupakan faktor penting dalam meningkatkan prestasi belajar. Adanya motivasi yang tinggi dalam belajar akan mengakibatkan hasil belajar yang baik. Menurut Sardiman (2010) motivasi merupakan faktor psikis yang bersifat non-intelektual. Peranannya yang khas adalah dalam hal menumbuhkan gairah agar siswa merasa senang dan semangat untuk belajar.

Keterampilan bertanya sangat penting dimiliki seorang guru, karena dapat meningkatkan partisipasi siswa dalam kegitan pembelajaran, membangkitkan minat dan rasa ingin tahu, mengembangkan pola berpikir dan cara belajar aktif, dan memusatkan perhatian siswa (Hasibun, 2008). Hal tersebut dipengaruhi oleh teknik bertanya, antara lain: kejelasan pertanyaan, pemberian acuan, pemindahan giliran, penyebaran, pemberian waktu berpikir, pemberian tuntutan (Saud, 2009). Untuk memudahkan menganalisis pertanyaan, pertanyaan biasanya diklasifikasikan berdasarkan pertimbangan tertentu. Dalam literatur tentang pertanyaan terdapat bermacam klasifikasi pertanyaan, diantaranya: pertanyaan akademik dan non akademik, pertanyaan tertutup dan terbuka, serta pertanyaan terkait proses kognitif (Widodo, 2006). Pertanyaan yang terkait proses kognitif merupakan taksonomi Bloom.

Menurut Rustaman (2005), keterampilan proses adalah keterampilan yang melibatkan keterampilan-keterampilan kognitif atau intelektual, manual dan sosial. Keterampilan kognitif terlibat karena dengan melakukan keterampilan proses siswa menggunakan pikirannya. Keterampilan manual jelas terlibat dalam keterampilan proses karena mereka melibatkan penggunaan alat dan bahan, pengukuran, penyusunan atau perakitan alat. Keterampilan sosial juga terlibat dalam keterampilan proses karena mereka berinteraksi dengan sesamanya dalam melaksanakan kegiatan belajar-mengajar, misalnya mendiskusikan hasil pengamatan. Keterampilan proses perlu dikembangkan melalui pengalaman-pengalaman langsung sebagai pengalaman belajar. Melalui pengalaman langsung, seseorang dapat labih menghayati proses atau kegiatan yang sedang dilakukan.

Dimensi proses kognitif mencakup menghafal, memahami, menerapkan, menganalisis, mengevaluasi, dan membuat (Widodo, 2006). Hasil penelitian relevan untuk memperkuat penelitian ini, yaitu penelitian yang dilakukan oleh Erni (2009), tentang kompetensi pedagogik dan professional bagi guru geografi di SMA Negeri di Kabupaten Pati, dilaporkan bahwa di sekolah dengan akreditasi A kemampuan bertanya guru termasuk kriteria baik $(78,8 \%)$, sedangkan guru di sekolah akreditasi B 45,8\% (kriteria kurang baik), sedangkan berdasarkan penelitian Wibowo (2006), tentang profil pertanyaan guru dan siswa dalam pelajaran sains dilaporkan sebagian besar pertanyaan yang ditanyakan guru merupakan pertanyaan kognitif dan pada jenjang mengingat (C1) dan memahami. Merealisasikan apa yang dipaparkan diatas diperlukan kreaktivitas guru dalam mengembangkan model-model pembelajaran yang meningkatkan kemampuan siswa dalam berketrampilan proses, karena terdapat keterkaitan erat antara pengembangan ketrampilan proses dengan pengalaman belajar. Makin aktif siswa secara intelektual, manual dan sosial akan semakin tampak bermakna pengalaman belajar siswa.

Menurut Rustaman (2003), keterampilan proses adalah keterampilan yang melibatkan keterampilan-keterampilan kognitif atau intelektual, manual dan sosial. Keterampilan kognitif terlibat karena dengan melakukan keterampilan proses siswa menggunakan pikirannya. Keterampilan manual jelas terlibat dalam keterampilan proses karena mereka melibatkan penggunaan alat dan bahan, pengukuran, penyusunan atau perakitan alat. 
Keterampilan sosial juga terlibat dalam keterampilan proses karena mereka berinteraksi dengan sesamanya dalam melaksanakan kegiatan belajar-mengajar, misalnya mendiskusikan hasil pengamatan. Keterampilan proses perlu dikembangkan melalui pengalaman-pengalaman langsung sebagai pengalaman belajar. Melalui pengalaman langsung, seseorang dapat labih menghayati proses atau kegiatan yang sedang dilakukan.

Hal ini sejalan dengan Kurukulum 2013 tentang aspek kerja ilmiah yang meliputi: penyelidikan/penelitian, berkomunikasi ilmiah, pengembangan kreaktivitas dan pemecahan masalah, sikap dan nilai ilmiah (Mulyasa, 2006). Indikator keterampilan proses sains menurut Dewi, (2008) terdapat 6 aspek yaitu keterampilan mengamati, keterampilan menyimpulkan, keterampilan mengukur, keterampilan memprediksi, keterampilan mengomunikasikan, dan keterampilan mengklasifikasikan. Namun pada penelitian kali ini keterampilan yang dipakai hanya empat keterampilan yaitu mengamati, menyimpulkan, memprediksi, dan mengomunikasikan.

Pertanyaan merupakan alat untuk merencanakan, mengajar, berpikir dan belajar. Bagi guru dalam pembelajaran, memakai pertanyaan dapat terjadi secara spontan dan sudah menjadi kebiasaan untuk memotivasi berpikir siswa. Kesulitan menunjukan guru tidak menyadari bahwa peningkatan mutu pertanyaan mereka dapat menghasikan peningkatan pembelajaran bagi siswanya. Dalam sains, pertanyaan siswa berperan penting dalam pembelajaran mereka. Apakah arti sebuah pertanyaan? Bagaimana menggunakan pertanyaan yang tepat dan bagaimana pengaruhnya? Apakah dampak pertanyaan terhadap siswa. Pertanyaan yang dipilih dan digunakan guru dapat mempengaruhi siswa dalam tiga alasan yaitu 1) sikap;2) cara berpikir; dan 3) prestasi belajar. Pertanyaan dapat digunakan untuk merangsang pengembangan ketrampilan proses sains dalam diri siswa (Susilo, 2003).

Pertanyaan yang berasal dari siswa dapat dipakai untuk mengembangkan masalah sains bagi inkuiri sains dan untuk mengembangkan kebiasan yang menguntungkan dan berguna yaitu melakukan refleksi. Pertanyaan siswa menunjukkan dunianya dan menggambarkan topic yang disenangi siswa. Pertanyaan siswa dapat mengejutkan guru yang meremehkan kemampuan siswa tertentu, dan menunjukan bahwa beberapa siswa tertentu memiliki kemampuan lebih dari pada fakta yang diperlihatkan dari bacaan dan pekerjaan tertulisnya. Pertanyaan siswa juga memberi petunjuk tentang apa yang diketahuinya, yang belum diketahuinya, dan apa yang ingin diketahuinya. Pertanyaan tersebut juga memberikan petunjuk tentang materi sains yang telah diketahuinya dan tingkatan konsep yang telah diketahuinya, apabila kita mau mendengarkannya dengan cermat. Pertanyaan juga dapat menunjukan keingintahuan, atau hanya karena terpaksa bertanya. Pertanyaan membantu siswa untuk mempertajam focus dan memperoleh pengetahuan yang menarik perhatiannya. Pertanyaan dapat pula sebagai cara untuk menarik perhatian. Pertanyaan dapat membantu siswa memecahkan suatu masalah, atau merupakan cara untuk meyakinkan suatu ide yang sebelumnya dimiliki. Pertanyaan siswa juga membantu mereka belajar lebih cepat. Apabila mereka belajar mengikuti kemauanya sendiri, belajar tentang yang ingin diketahuinya, hasilnya akan lebih cepat dan meliputi pengetahuan yang luas, daripada yang ingin kita rencanakan.

Memaksa siswa untuk bertanya menimbulkan kebiasaan yang baik dalam melakukan refleksi. Membentuk kebiasaan membutuhkan waktu, dan mengajukan pertanyaan menjadikan kebiasaan yang dapat memperkaya kurikulum sekolah. Waktu yangdibutuhkan untuk merenung akan membantu mengembangkan kebiasaan ini. Bertanya pada diri sendiri dan memperkirakan jawabannya menyebabkan berpikir kreaktif, merupakan sarana untuk memecahkan masalah yang pelik dan dapat membantu seorang anak untuk belajar "menemukan situasi yang menyenangkan, dimana orang lain merasa jemu" (Biddueph, Symington \& Osborn, 1986 dalam Martin, et al, 1997).

Bagaimanakan caranya mengajak siswa untuk bertanya? terdapat empat factor yang memacu siswa untuk bertanya. Apabila guru ingin siswa bertanya lebih banyak, maka perlu diberi stimulus, menjadi model 
mengajukan pertanyaan, mengembangkan suasana kelas yang menghargai bertanya, dan menggunakan pertanyaan untuk mengevaluasi siswa. Guru Biologi hendaknya membantu siswa menjadi seorang warga Negara yang pemikir kritis, pemecah masalah, dan literat IPA. Apabila guru ini agar siswanya berfungsi sebagai pemikir yang mandiri, guru harus memberi kesempatan dalam kelas kepada siswa untuk lebih terlibat dan berinisiatif dalam kegiatan. Hal ini berarti menggeser peranan guru sebagai pemberi informasi ke fasilitator dan pembimbing dalam proses belajar. Guru dapat melakukan hal ini melalui pertanyaanpertanyaan yang diajukan.

\section{METODE}

$\begin{array}{rrr}\text { Penelitian } & \text { ini } & \text { dilaksanakan } \\ \text { menggunakan } & \text { rancangan } & \text { Penelitian }\end{array}$ Tindakan Kelas (PTK) ini dilaksanakan secara kolaborasi dengan guru Biologi kelas VII dan wakil kepala sekolah urusan Kurikulum di SMP Negeri 6 Ambon. PTK ini dilaksanakan di kelas $\mathrm{VII}_{1}$ sedangkan kelas $\mathrm{VII}_{2}$ digunakan sebagai uji coba model pembelajaran. Penelitian ini menggunakan Rancangan Penelitian tindakan menggunakan prosedur yang dikembangkan oleh Kemmis \& Taggrat dalam Arikunto, 2011 dengan rancangan bersiklus yang akan dihentikan jika kelima aspek kualitas pembelajaran (Performnece guru, fasilitas pembelajaran, iklim, sikap dan motivasi belajar siswa) maupun ketuntasan hasil belajar siswa sebagai data pendukung telah mencapai terget yang ditetapkan yaitu sebesar 75\% (Mulyasa, 2006).

Prosedur penelitian meliputi 4 tahapan yaitu: perencanaan (planning), dan tindakan (action), observasi (observation), dan refleksi (reflection). Penelitian ini melibatkan 2 guru biologi sebagai teman pada kelopok Guru mata pelajaran (MGMP) yang akan membantu peneliti dalam penilaian teman sejawat dan penilaian lainnnya.

Perencanaan pada siklus I terdiri atas kegiatan: (1) observasi awal dan diskusi tentang permasalahan PBM Biologi; (2) diskusi tentang PBM Biologi menggunakan skenario pembelajaran pendekatan kerja ilmiah bertanya dengan ketrampilan belajar proses; (3) menyusun persiapan pembelajaran dan elvaluasinya, dan (4) menyusun jadwal pelaksanaan. Pelaksanaan terdiri atas kegiatan: (1) pemberian tes awal; (2) penyelidikan dan diskusi hasil penyelidikan, (3) pengamatan dan diskusi hasil pengamatan. Selama pelaksanaan dilakukan pengamatan terhadap aktivitas guru oleh dua pengamat, yaitu peneliti dan wakil kepala sekolah menggunakan format penelitian aktivitas guru. Tahap evaluasi berupa tes akhir. Refleksi adalah tahap mendiskusikan hasil tes akhir dan hasil pengamatan terhadap aktivitas guru, serta bagaimana tindak lanjut untuk siklus berikutnya.

Indikator keterampilan proses sains terdapat 6 aspek yaitu keterampilan mengamati, keterampilan menyimpulkan, keterampilan mengukur, keterampilan memprediksi, keterampilan mengomunikasikan, dan keterampilan mengklasifikasikan. Namun pada penelitian kali ini keterampilan yang dipakai hanya empat keterampilan yaitu mengamati, menyimpulkan, memprediksi, dan mengomunikasikan. Selanjutnya untuk mengukur aspek keterampilan Proses Sains aspek-aspek yang dinilai dijelaskan dalam tabel 1.

Tabel 1. Aspek Ketrampilan Proses

\begin{tabular}{|c|c|c|c|c|c|}
\hline \multirow[b]{2}{*}{ No } & \multirow{2}{*}{$\begin{array}{c}\text { Aspek Ketrampilan } \\
\text { Proses }\end{array}$} & \multicolumn{4}{|c|}{ Skor } \\
\hline & & $\begin{array}{c}4 \\
\text { (sangat baik) }\end{array}$ & $\begin{array}{c}3 \\
\text { (Baik) }\end{array}$ & $\begin{array}{c}2 \\
\text { (Cukup) }\end{array}$ & $\begin{array}{c}1 \\
\text { (kurang) }\end{array}$ \\
\hline 1 & Mengamati & $\begin{array}{l}\text { Mengamati } \\
\text { bagian } \\
\text { tumbuhan } \\
\text { secara } \\
\text { terampil dan } \\
\text { tepat sesuai } \\
\text { tujuan dan } \\
\text { cirri khusus }\end{array}$ & $\begin{array}{l}\text { Mengamati } \\
\text { bagian } \\
\text { tumbuhan } \\
\text { secara terampil } \\
\text { dan tepat }\end{array}$ & $\begin{array}{l}\text { Mengamati } \\
\text { bagian } \\
\text { tumbuhan } \\
\text { secara terampil }\end{array}$ & $\begin{array}{l}\text { Mengamati } \\
\text { bagian } \\
\text { tumbuhan } \\
\text { secara terampil } \\
\text { dan tepat tetapi } \\
\text { tidak sesuai } \\
\text { tujuan dan cirri } \\
\text { khusus }\end{array}$ \\
\hline
\end{tabular}


2 Mengukur

3 Mengklasifikasikan

$4 \quad$ Memprediksi

5 Mengkumunikasikan

6 Menyimpulkan

$\begin{array}{ll}\text { Mengukur } & \text { Mengukur } \\ \text { bagian } & \text { bagian } \\ \text { tumbuhan } & \text { tumbuhan } \\ \text { secara } & \text { secara terampil } \\ \text { terampil dan } & \text { dan tepat } \\ \text { tepat sesuai } & \\ \text { tujuan dan } & \\ \text { cirri khusus } & \end{array}$
kan berbagai jenis tumbuhan secara terampil dan tepat sesuai tujuan dan cirri khusus

Memahami dengan benar fakta hasil identifikasi tumbuhan dan membuat prediksi

Mengkomunik asikan dengan cara pengelompok -kan ciri tumbuhan dilanjutkan sampai dihasilkan kelompok yang tidak dapat dibagibagi lagi ke dalam kelompok yang lebih kecil, sehingga akan ditemukan nama dari tumbuhan tersebut. Memahami konsep dan menyimpulka $\mathrm{n}$ untuk mengaplikasi pada konsep lain
Mengukur
bagian
tumbuhan
secara terampil

Mengklasifikasi kan berbagai jenis tumbuhan secara terampil jenis tumbuhan

Memahami dengan benar fakta hasil identifikasi

tumbuhan secara terampil dan tepat

Mengukur bagian tumbuhan secara terampil dan tepat tetapi tidak sesuai tujuan dan cirri khusus

Mengklasifikasi kan berbagai jenis tumbuhan secara terampil dan tepat tetapi tidak sesuai tujuan dan cirri khusus

Memahami
hanya
beberapa fakta
hasil identifikasi
tumbuhan

Memahami dengan benar fakta hasil identifikasi tumbuhan tetapi tidak membuat prediksi

Mengkomunika sikan dengan cara pengelompokkan cirri tumbuhan dilanjutkan sampai dihasilkan kelompok kecil.

Mengkomunika Mengkomunika sikan dengan cara pengelompokka n cirri tumbuhan tidak dilanjutkan sampai dihasilkan kelompok yang tidak dapat dibagi-bagi lagi ke dalam kelompok yang lebih kecil, sehingga tidak ditemukan nama dari tumbuhan tersebut.

$\begin{array}{ll}\text { Memahami } & \text { Memahami } \\ \text { konsep yang } & \text { hanya } \\ \text { telah dipelajari } & \text { beberapa } \\ & \text { konsep }\end{array}$

Tidak memahami konsep dan miskonsepsi 


\section{HASIL DAN PEMBAHASAN}

\section{Hasil Analisis Aktivitas Guru}

Strategi pembelajaran yang digunakan pada Kurikulum 2013 Kerja IImih Bertanya yang menekankan pada siswa untuk lebih aktif lagi. Kerja Ilmih Bertanya terdiri dari aspek mengamati, menanya, mencoba, menganalisis dan mengkomunikasikan sehingga siswa mampu berfikir secara kritis-kreatif. Pengamatan tehadap kemampuan guru SMP 6 sebagai sekolah sampel dalam menggunakan Kerja IImih Bertanya terdiri dari beberapa aspek komponen kemudian di cari persentasenya, maka didapatkan hasil yang di sajikan dalam bentuk tabel 1 .

Berdasarkan tabel 1 hasil observasi kemampuan guru dalam pelaksanaan pembelajaran berdasarkan Kurikulum 2013 di SMP 6 menggunakan Kerja IImiah Bertanya menunjukkan bahwa pada komponen kegiatan pendahuluan sudah baik $(83.31 \%)$ pada siklus III. Data yang diperoleh dari pengamatan guru pada saat melakukan apersepsi, memberi motivasi dan penyampaian tujuan.

Tabel 1. Rekapitulasi Data Hasil Observasi Kemampuan Guru Dalam Melaksanaan Proses Pembelajaran Berdasarkan Kurikulum 2013 Menggunakan Kerja IImiah Bertanya.

\begin{tabular}{|c|c|c|c|c|}
\hline Komponen & Aspek & $\frac{\text { siklus }}{\text { I }}$ & $\begin{array}{c}\text { siklus } \\
\text { II }\end{array}$ & $\frac{\text { siklus }}{\text { III }}$ \\
\hline \multirow[t]{5}{*}{ Pendahuluan } & apersepsi, motivasi, penyampaian tujuan & 72 & 75 & 77 \\
\hline & Menguasai Materi Pelajaran & 70 & 75 & 77 \\
\hline & Strategi Pembelajaran yang Mendidik & 78.55 & 80.10 & 90.55 \\
\hline & Menerapkan kerja Ilmiah bertanya & 80,55 & 85,10 & 90,55 \\
\hline & Menerapkan Pembelajaran Terpadu & 75 & 77 & 85 \\
\hline \multirow{4}{*}{$\begin{array}{l}\text { Kegiatan } \\
\text { Inti }\end{array}$} & Memanfaatkan Sumber/Media & 75 & 77 & 87 \\
\hline & Pembelajaran & & & \\
\hline & $\begin{array}{l}\text { Pelibatan Peserta Didik dalam } \\
\text { Pembelajaran }\end{array}$ & 70,55 & 80,33 & 90,22 \\
\hline & $\begin{array}{l}\text { Menggunakan Bahasa yang Benar dan } \\
\text { Tepat }\end{array}$ & 73,44 & 75,33 & 88,33 \\
\hline \multirow[t]{2}{*}{ Penutup } & Menerapkan langkah menutup pelajaran & 74,33 & 75,55 & 76,67 \\
\hline & Rata-rata & 74,11 & 76,82 & 83,31 \\
\hline
\end{tabular}

Sumber: Departemen Pendidikan Nasional, 2013

Komponen kegiatan inti pada kedua sekolahan sudah terlihat sudah sangat baik mencapai (90.55\%) siklus ke III. Hal ini terlihat sudah baik karena pada aspek menguasai materi pelajaran, menerapkan strategi pembelajaran yang mendidik, menerapkan kerja Ilmiah bertanya (pendekatan berbasis proses keilmuan), menerapkan pembelajaran IPA terpadu intra-mata pelajaran IPA (hanya untuk mata pelajaran yang relevan), memanfaatkan sumber belajar/media dalam pembelajaran, pelibatan peserta didik dalam pembelajaran, menggunakan bahasa yang benar dan tepat dalam pembelajaran sudah terlihat baik. Komponen penutup pembelajaran pada kedua sekolahan sudah terlihat sudah sangat baik (76.67\%). Hal ini terlihat sudah baik karena guru mampu membuat rangkuman dengan melibatkan peserta didik, melakukan refleksi yang mengkaitkan materi pelajaran dengan sikap spiritual dan social. Namun, terkadang guru tidak memberi tindak lanjut dengan memberi arahan kegiatan berikutnya dan/atau tugas pengayaan atau remidi.

Berdasarkan hasil tersebut dapat disimpukan bahwa dalam kemampuan guru dalam penggunaan strategi pembelajaran berdasarkan Kurikulum 2013 di kelas VII SMP 6 Ambon sudah sangat baik (83.319\%). Hasil yang diperoleh dalam penelitian ini diperkuat dengan hasil penelitian dari Pertiwi (2013), bahwa terjadi peningkatan sikap ilmiah siswa dengan menggunakan pembelajaran kerja ilmiah bertanya. Sikap ilmiah yang mengalami peningkatan adalah sikap ingin tahu, sikap berfikir kritis dan sikap kerjasama dengan 
rata- rata persentase peningkatannya hal ini terbukti dengan pertanyaan-pertnyaan yang dikemukakan oleh siswa. Utami (2012) dalam penelitianya juga menyatakan bahwa dengan kerja ilmiah Bertanya dalam pembelajaran, peserta didik dapat mengembangkan potensi berpikir dan lebih bermakna, karena peserta didik langsung dihadapkan dengan permasalahan yang nyata. Ma'mur (2009), menyatakan bahwa guru harus menguasai minimal satu bidang keilmuan sesuai dengan bidang yang telah dijalani pada masa kuliah. Seperti halnya guru IPA harus mengajar dibidang IPA tidak boleh dibidang lain yang bukan keahliannya. Guru harus memiliki sikap integritas professional.

Penggunaan kerja IImiah bertanya oleh guru SMP Negeri 6 Ambon dalam melaksanakan proses pembelajaran dikelas berdasarkan hasil pengamatan sangat bermanfaat bagi pemenuhan rasa ingin tahu peserta didik. Sehingga proses pembelajaran memiliki kebermaknaan yang tinggi. Kegiatan mengamati dalam pembelajaran sebagaimana diatur dalam Permendikbud Nomor 81A/2013, hendaklah guru membuka secara luas dan bervariasi kesempatan kepada peserta didik untuk melakukan pengamatan melalui kegiatan: melihat, menyimak, mendengar, dan membaca. Guru memfasilitasi peserta didik untuk melakukan pengamatan, melatih mereka untuk memperhatikan (melihat, membaca, mendengar) hal yang penting dari suatu benda atau objek. Adapun kompetensi yang diharapkan adalah dibutuhkan kemampuan guru untuk berpikir secara kreatif dalam melahirkan ide-ide melatih peserta didik untuk ada dalam kesungguhan, ketelitian, dan mencari informasi.

Kegiatan menanya yang dilakukan oleh guru dengan memfasilitasi siswa untuk dapat menemukan pertanyaan-pertanyaan yang berkaitan dengan suatu hal yang diamati oleh siswa baik dari buku teks, gambar, pengamatan tumbuhan di lingkungan maupun video pembelajaran sudah sangat baik (90\%). Dalam hal ini guru yang efektif mampu menginspirasi peserta didik untuk meningkatkan dan mengembangkan ranah sikap, keterampilan, dan pengetahuannya. Pada saat guru bertanya, terlihat dengan jelas bagaimana kreatif berpikir guru untuk melahirkan pertanyaan- pertanyaan yang membimbing atau memandu peserta didiknya belajar dengan baik. Ketika guru menjawab pertanyaan peserta didiknya, ketika itu guru mendorong siswa untuk menjadi penyimak dan pembelajar yang baik. Artinya dengan kreatifitas guru dapat menumbuhkan sikap ingin tahu siswa, yang diekspresikan dalam bentuk pertanyaan.

Kegiatan mengumpulkan informasi dapat dilakukan dengan menemukan suatu informasi dari tumbuhan yang diamati siswa dalam kehidupan sehari-hari. Menemukan informasi tidak hanya dilakukan ketika siswa mengamati tumbuhan di laboratorium, tetapi guru sudah mampu memotivasi anak mendapatkan informasi melalui mengidentifikasi tumbuhan lain yang ditemukan di luar kelas atau lingkungan kehidupan sehari-harinya. Kegiatan "mengidentifikasi tumbuhan lain yang ditemukan di luar kelas" merupakan tindak lanjut dari bertanya. Kegiatan ini dilakukan dengan menggali dan mengumpulkan informasi dari berbagai sumber melalui berbagai cara. Untuk itu guru harus lebih memotivasi peserta didik mencari literatur yang lebih banyak terkait dengan tumbuhan yang diidentifikasi, memperhatikan berbagai permasalahan terkait tumbuhan yang teliti.

Tahap terakhir pelaksanaan Kerja IImiah Bertanya dalam kegiatan mengkomunikasikan yaitu guru sudah memberi kesempatan kepada peserta didik untuk mengkomunikasikan hasil identifikasi tumbuhan. Kegiatan ini dilakukan guru melalui menjelaskan apa yang ditemukan dalam melakukan identifikasi tumbuhan yang ditemukan berdasarkan tingkat taksonnya, mengasosiasikan dan menemukan pola identifikasi tumbuahan. Hasil identifikasi tumbuhan tersebut disampikan di kelas dan dinilai oleh guru sebagai hasil belajar peserta didik atau kelompok peserta didik tersebut. Kegiatan "mengkomunikasikan" dalam kegiatan pembelajaran sebagaimana disampaikan dalam Permendikbud Nomor 81A Tahun 2013, adalah menyampaikan hasil pengamatan, kesimpulan berdasarkan hasil analisis secara lisan, tertulis, atau media lainnya. 


\section{Katuntasan Belajar Siswa}

Peningkatan hasil belajar siswa setelah proses pembelajaran menggunakan kerja ilmiah bertanya menunjukkan hasil belajar kognitif, afektif dan psikomotorik telah mencapai ketuntasan klasikal yang ditetapkan, yakni > 85\%. Salah satu cara untuk menciptakan pembelajaran yang bermakna adalah dengan menerapkan pendekatan saintifik. Menurut Fauziah
(2013) ketrampilan proses sains mengajak siswa langsung dalam menginferensi masalah yang ada dalam bentuk rumusan masalah dan hipotesis, rasa peduli terhadap lingkungan, rasa ingin tahu dan gemar membaca. Dalam pelaksanaanya, siswa akan memperoleh kesempatan untuk melakukan penyelidikan dan inkuiri serta mengembangkan dan menyajikan hasil karya.

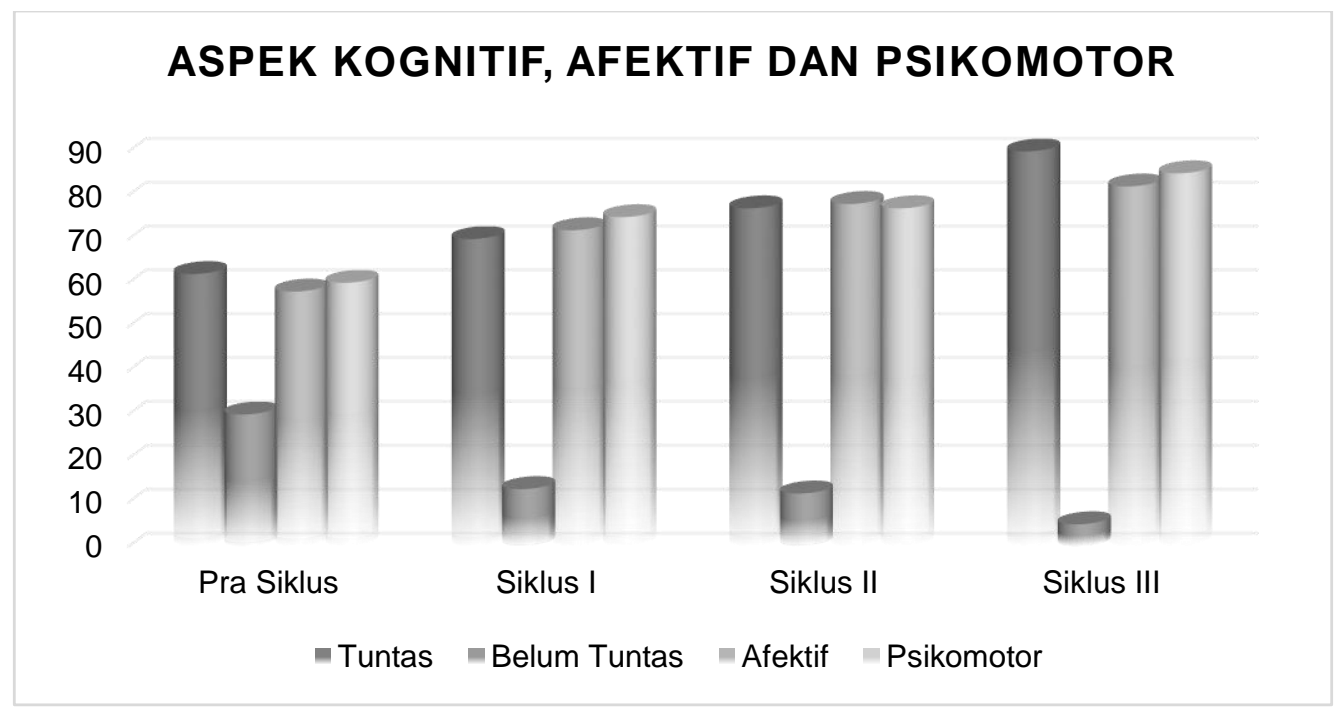

\section{Gambar 1. Grafik Ketuntasan Belajar Siswa Kognitif, Afektif dan Psikomor}

Melalui kerja ilmiah bertanya, hasil belajar siswa (kemampuan kognitif, afektif dan psikomotor) siswa akan dirangsang untuk berpikir secara analisis, berperilaku jujur, disiplin, kreatif dan mandiri. Kegiatan menyajikan hasil karya akan menimbulkan perilaku kreatif, menghargai prestasi yang telah ada, bertanggungjawab terhadap hasil karya, kemampuan bekerjasama dan berkomunikasi yang baik. Pada tahap akhir siswa akan diajak menganalisis dan mengevaluasi proses pemecahan masalah. Pada tahap ini siswa akan berpikir pada tingkat analisis dan evaluasi karena harus melakukan refleksi terhadap proses yang mereka lakukan.

Berdasarkan uraian data pada gambar 1, terlihat betapa pentingnya kerja ilmiah bertanya digunakan dalam pembelajaran dikelas, karena kerja ilmiah bertanya dapat mengembangkan berbagai skill seperti keterampilan berpikir kritis (critical thinking skill), keterampilan berkomunikasi (communication skill), keterampilan melakukan kerja sama dan penyelidikan (research and collaboration skill) dan perilaku berkarakter, karena pengalaman belajar yang diberikan dapat memenuhi tujuan pendidikan dan bermanfaat bagi pemecahan masalah dan kehidupan nyata. Dibutuhkan kerja keras guru memfasilitasi peserta didik untuk melakukan pengamatan, melatih mereka untuk memperhatikan (melihat, membaca, mendengar) hal yang penting dari suatu benda atau objek. Hal ini sangat berpengaruh terhadap ketuntasan belajar siswa.

Faktor lain yang mempengaruhi peningkatan motivasi siswa tiap siklus adalah kualitas pembelajaran yang semakin baik. Proses pembelajaran pada tahap siklus III lebih baik dibandingkan siklus I dan II, sedangkan pembelajaran siklus I lebih baik dibandingkan pra-siklus. Peningkatan kualitas dan keterlaksanaan proses pembelajaran mengakibatkan ketercapaian skor tiap aspek menjadi lebih tinggi. Kualitas pembelajaran dikelola oleh guru. Guru 
melakukan perbaikan pembelajaran pada tiap siklus melalui tahap refleksi dan perencanaan kembali sebagai upaya perbaikan di siklus berikutnya. Semakin baik kualitas pembelajaran yang dikelola oleh guru di kelas, semakin besar peningkatan kualitas siswa.

\section{Aspek Iklim Belajar Siswa}

Penciptaan iklim belajar yang kondusif dalam penelitian ini adalah suasana yang aman, nyaman, dan menyenangkan. Dilihat dari peranan guru sebagai seorang pendidik, pembimbing, pelatih, dan pemimpin yang dapat menciptakan iklim kelas yang menarik, aman, nyaman dan kondusif, keberadaanya di tengah-tengah siswa dapat mencairkan suasana kebekuan, kekakuan dan kejenuhan belajar yang terasa berat diterima oleh para siswa. Iklim kelas yang tidak kondusif akan berdampak negatif terhadap proses pembelajaran dan sulitnya tercapai tujuan pembelajaran, siswa akan merasa gelisah, resah, bosan dan jenuh. Sebaliknya dengan iklim kelas yang kondusif dan menarik dapat dengan mudah mencapai tujuan pembelajaran, dan proses pembelajaran yang dilakukan menyenangkan bagi peserta didik. Iklim kelas adalah suasana dan kondisi kelas dalam hubungannya dengan kegiatan pembelajaran. Iklim kelas merupakan suasana yang ditandai oleh adanya pola interaksi atau komunikasi antara guru-siswa, siswa-guru dan siswa-siswa. Tugas guru yang paling utama adalah mengkondisikan lingkungan belajar mengajar agar menunjang terjadinya perubahan perilaku bagi peserta didik (Irawan, 2014).

Tabel 2. Data Observasi Peningkatan Iklim Pembelajaran

\begin{tabular}{clcrrc}
\hline No & Aspek Iklim Belajar & Pra Siklus & Siklus I & Siklus II & Siklus III \\
\hline 1 & Kekompakan Siswa & 75,0 & 75,0 & 85,7 & 92,9 \\
2 & Keterlibatan Siswa & 82,1 & 82,1 & 89,3 & 92,9 \\
3 & Kepuasan Siswa & 75,0 & 75,0 & 89,3 & 96,4 \\
4 & Dukungan Guru & 64,3 & 64,3 & 71,4 & 89,3 \\
\hline & Rata-rata & $\mathbf{7 4 , 1}$ & $\mathbf{7 4 , 1}$ & $\mathbf{8 3 , 9}$ & $\mathbf{9 2 , 9}$ \\
\hline
\end{tabular}

Sumber: Cahyaningratri (2012); Suparmi (2012).

Penciptaan iklim belajar yang kondusif dalam penelitian ini adalah suasana yang aman, nyaman, dan menyenangkan. Hal ini nampak dari data tabel 2 bahwa pada siklus ke III suasana pembelajaran menjadi sangat baik. Hal ini sebabkan pada siklus I dan II siswa terus diproses sehinga pada siklus ke III iklim siswa sudah mampu beradaptasi dengan baik. Dengan iklim belajar yang kondusif tersebut dapat membuat siswa merasa nyaman dalam belajar yang pada akhirnya dapat membangkitkan gairah dan semangat siswa dalam belajar. Apalagi kegiatan mengidentifikasi tumbuhan merupakan hal yang cukup sulit dan membosankan bila tidak didukung oleh iklim belajar yang nyaman. Begitu juga sebaliknya, iklim belajar yang tidak kondusif membuat siswa merasa bosan dan tidak semangat dalam belajar. Penciptaaan iklim belajar yang kondusif mempnyai beberapa syarat berdasarkan observasi langsung yang peneliti lakukan, syarat penciptaan iklim belajar yang kondusif di kelas VII SMP Negeri 6 adalah sebagi berikut: 1) Pengembangan layanan belajar, diantaranya yaitu: pemberian tugas yang memotivasi siswa, penyampaian materi yang menarik, sikap yang harmonis anatara guru dan siswa, anatara siswa itu sendiri, dan pemberian motivasi oleh guru. 2) Pengelolaan siswa, diantaranya yaitu: sikap tanggap guru dalam membagi perhatian, memusatkan perhatian kelompok, menegur siswa, dan memberikan penguatan. 3) Pengelolan fisik, diantaranya yaitu: pengaturan sarana belajar, susunan tempat duduk, penerangan, dan suhu.

Hal tersebut diatas juga didukung oleh data hasil observasi siswa dan data hasil wawancara dengan guru yang mengajar, yang menyatakan bahwa syarat iklim belajar yang kondusif adalah: kondisi atau keadaan gedung yang baik, sumber pembelajaran seperti buku yang lengkap, perpustakaan yang lengkap, pengaturan lingkungan 
belajar, seperti papan tulis, tempat duduk, dan perabot yang ada dalam kelas harus tertata dengan tepat, penampilan dan sikap guru, kebersihan dan disiplin sekolah dan keaktifan serta semangat siswa dalam belajar. Berdasarkan hasil wawancara juga sudah terlihat bahwa sudah ada usaha dari pihak guru terutama guru yang mengajar dalam menciptakan suasana belajar yang aman, nyaman, tertib dan menyenangkan seperti memberikan motivasi kepada siswa agar siswa lebih giat belajar, memberikan teguran pada siswa yang menggangu siswa yang lain dalam belajar, menunjukkan sikap yang akrap dengan cara memberikan teguran dengan sapaan yang menyenangkan, menciptakan hubungan yang harmonis, memberikan kesempatan pada siswa bertanya pada saat proses belajar mengajar berlangsung. Hasil belajar merupakan suatu perolehan perilaku untuk membantu kecakapan, kebiasaan, sikap, penguasaan dan penghargaan dalam individu belajar.

\section{Motivasi Belajar Siswa}

Menurut Sardiman (2011) motivasi belajar adalah keseluruhan daya penggerak di dalam diri siswa yang menimbulkan kegiatan belajar, yang menjamin kelangsungan dari kegiatan belajar dan yang memberikan arah pada kegiatan belajar, sehingga tujuan yang dikehendaki oleh subjek belajar dapat tercapai. Sama halnya menurut Dimyati dan Mujiono (2009) yang menyatakan bahwa motivasi merupakan dorongan mental yang menggerakkan dan mengarahkan perilaku manusia, termasuk dalam kegiatan belajar motivasi mendorong seseorang untuk belajar untuk mencapai tujuan yang diinginkannya.

Jadi dapat disimpulkan motivasi belajar merupakan keseluruhan daya pendorong atau penggerak di dalam diri siswa yang menimbulkan kegiatan belajar dan yang memberikan arah pada kegiatan belajar, sehingga tujuan yang dikehendaki siswa dapat tercapai. Motivasi akan membangkitkan semangat dalam belajar. Apabila motivasi siswa dalam belajar tinggi, maka hasil belajarnya akan optimal dan sebaliknya jika motivasi belajar siswa rendah, maka hasil belajar akan menjadi kurang maksimal.

Tabel 3. Motivasi Belajar Siswa.

\begin{tabular}{|c|c|c|c|c|c|}
\hline No & $\begin{array}{c}\text { Aspek Performance } \\
\text { Siswa }\end{array}$ & $\begin{array}{c}\text { PraSiklus } \\
\%\end{array}$ & Siklus $1 \%$ & Siklus II\% & Siklus III\% \\
\hline 1 & $\begin{array}{l}\text { Sensitif terhadap } \\
\text { peningkatan prestasi }\end{array}$ & 62.1 & 72.5 & 75.2 & 87.1 \\
\hline 2 & $\begin{array}{l}\text { Kegiatan untuk } \\
\text { mencapai prestasi }\end{array}$ & 60.5 & 62.5 & 75.0 & 90.7 \\
\hline 3 & $\begin{array}{l}\text { Cermat menentukan } \\
\text { target prestasi }\end{array}$ & 51.3 & 70.0 & 66.8 & 85.2 \\
\hline 4 & $\begin{array}{l}\text { Usaha mengatasi } \\
\text { hambatan }\end{array}$ & 62.7 & 65.6 & 70.5 & 82.4 \\
\hline 5 & $\begin{array}{l}\text { Menemukan cara } \\
\text { penyelesaian } \\
\text { masalah }\end{array}$ & 56.3 & 60.7 & 70.5 & 82.4 \\
\hline 6 & Menyukai tantangan & 52.4 & 63.3 & 68.8 & 80.7 \\
\hline 7 & $\begin{array}{l}\text { Kesempurnaan } \\
\text { penyelesaian tugas }\end{array}$ & 61.8 & 68.9 & 79.7 & 84.1 \\
\hline 8 & $\begin{array}{l}\text { Melakukan diskusi } \\
\text { dengan baik }\end{array}$ & 57.8 & 65.4 & 68.8 & 84.1 \\
\hline 9 & $\begin{array}{l}\text { Percaya diri dalam } \\
\text { menyelesaikan tugas }\end{array}$ & 50.5 & 70.3 & 75 & 85.9 \\
\hline & Rata-rata & 57.27 & 66.58 & 72.26 & 84.73 \\
\hline
\end{tabular}

Sumber: Cahyaningratri (2012); Suparmi (2012). 
Hasil pengukuran motivasi belajar siswa kelas VII SMP Negeri 6 pada siklus I, II dan siklus III menunjukkan kenaikan yang cukup signifikan dibanding dengan rata-rata pra siklus. Kenaikan rata-rata hasil tes dari siklus I ke siklus II sebesar $5.68 \%$ sedangkan pada siklus II ke siklus III mengalami kenaikan sebesar 12.47 .

Data pada tabel 3 rata-rata total hasil pengukuran motivasi siswa pada siklus III mengalami peningkatan yang cukup signifikan sebesar $84,73 \%$. Hal ini memberikan gambaran bahwa siswa sangat sensitif terhadap peningkatan prestasi. Siswa memiliki motivasi yang kuat terhadap peningkatan prestasi dibuktikan dengan tingkat aktivitas kegiatan siswa untuk mencapai prestasi cukup tinggi yakni sebesar $90.7 \%$. Siswa memiliki kecermatan yang tinggi terhadap prestasi yang dicapai dan mempunyai usaha yang kuat bila menghadapi hambatan.

Siswa mempunyai kemampuan untuk menemukan cara penyelesaian masalah dan menyukai tantangan. Hal ini dibuktikan dengan volume pertanyaan siswa yang cukup banyak dalam mempelajari sistem klasifikasi tumbuhan. Dalam menyelesaikan tugas yang diberkan oleh guru siswa berupaya untuk dapat mencapai kesempurnaan dengan baik. Setiap tugas yang diberikan oleh guru, siswa sudah mulai terbiasa melakukan diskusi dengan baik dan mempunyai percaya diri yang tinggi dalam menyelesaikan tugas-tugas. Motovasi belajar siswa ditunjukkan dengan makin banyak pertanyaan tentang tumbuhan oleh siswa. Hasil penelitian ini sesuai dengan pendapat Sardiman, (2011) bahwa motivasi belajar menimbulkan kegiatan belajar, menjamin kelangsungan dari kegiatan belajar, sehingga tujuan dari kegiatan belajar tersebut dapat tercapai. Tujuan dari kegiatan belajar disini adalah termasuk memperoleh prestasi belajar yang baik. Kemudian juga sejalan dengan pendapat Uno, (2007) bahwa siswa yang memiliki motivasi belajar yang tinggi, akan tekun dalam belajar sehingga berhasil dalam belajarnya.

Selain sejalan dengan kedua pendapat di atas, hasil penelitian ini juga sejalan dengan penelitian Hamdu dan Agustina (2011); Widodo dan Ellyana (2011); Zahroul dan Dwi (2011) yang menyebutkan bahwa ada pengaruh signifikan antara motivasi belajar siswa terhadap prestasi belajar siswa. Berdasarkan hasil penelitian dapat dijelaskan bahwa motivasi belajar menunjukkan pengaruh positif terhadap prestasi belajar siswa. Kegiatan belajar siswa sangat membutuhkan adanya motivasi belajar dalam mencapai prestasi yang baik. Dengan adanya motivasi, siswa akan mempunyai semangat belajar yang tinggi serta mampu menciptakan suasana yang kondusif dan interaktif dalam proses belajar mengajar. Dengan demikian, motivasi juga dapat berfungsi sebagai perangsang dalam belajar, karena motivasi yang mendorong dan menggerakkan siswa untuk belajar sehingga memperoleh hasil belajar yang baik.

Guru diharapkan senantiasa menumbuhkan motivasi belajar siswa, sehingga siswa lebih tekun dan rajin dalam belajar. Cara menumbuhkan motivasi belajar tersebut misalnya dengan memberikan reward berupa pujian saat proses belajar menagajar, memberikan hadiah kepada siswa yang aktif dalam pelajaran, memberi ulangan secara mendadak agar siswa selalu siaga belajar sebelum pelajaran dimulai, dan lain sebagianya.

Siswa diharapkan lebih meningkatkan motivasi belajarnya, serta memanfaatkan fasilitas belajar dengan baik untuk mendukung proses belajar mengajar agar bisa meningkatkan prestasi belajarnya. Sekolah perlu memperhatikan motivasi siswanya, pemberian motivasi akan meningkatkan semangat siswa dalam belajar. Peran pihak sekolah dalam menumbuhkan motivasi misalnya dengan memberikan penghargaan-penghargaan kepada siswa berprestasi disekolah. Prestasi belajar yang diperoleh siswa tidak hanya dipengaruhi oleh dua faktor tersebut, akan tetapi prestasi belajar siswa juga dipengaruhi oleh faktor-faktor lain seperti sikap, bakat, minat, intelegensi, gaya belajar, lingkungan belajar, disiplin belajar, kebiasaan belajar, kurikulum dan lain sebagainya. Oleh karena itu, peneliti selanjutnya dapat meneliti faktor-faktor lain yang dapat mempengaruhi prestasi belajar selain motivasi dan pemanfaatan fasilitas belajar. 


\section{Aspek Ketrampilan Proses}

Keterampilan siswa yang diperlukan untuk menguasai pengetahuan dan mampu memanfaatkan pengetahuan yang didapat dalam pemecahan masalah sehari-hari adalah keterampilan proses sains (Aydogdu, 2015; Chabalengula dkk, 2012; Deniz, 2013; Hirca, 2015; Kruea-In dkk, 2015; Wilhelm dkk, 2007; Yakar, 2014 dalam Bachtiar,
2015). Sedangkan keterampilan proses sains siswa dapat dikembangkan ketika proses pembelajaran di kelas. Dengan demikian, guru harus mampu mendesain pembelajaran yang mampu mengembangkan Keterampilan Proses Sains siswa. Hasil analisis ketrampilan proses sains siswa dijelaskan pada tabel 4.

Tabel 4. Hasil Analisis Ketrampilan Proses Sains Siswa.

\begin{tabular}{lccccl}
\hline $\begin{array}{c}\text { Aspek Ketrampilan } \\
\text { Proses }\end{array}$ & $\begin{array}{c}\text { Pra } \\
\text { Siklus }\end{array}$ & $\begin{array}{c}\text { Siklus } \\
\text { I }\end{array}$ & $\begin{array}{c}\text { Siklus } \\
\text { II }\end{array}$ & $\begin{array}{c}\text { Siklus } \\
\text { III }\end{array}$ & Kategori \\
\hline Mengamati & 2 & 2,66 & 3.52 & 3,76 & Baik \\
Mengukur & 3 & 3.22 & 3,67 & 4 & Sangat baik \\
Mengklasifikasikan & 2,25 & 3.33 & 3.77 & 4 & Sangat baik \\
Memprediksi & 2,1 & 3 & 3.55 & 3.8 & Baik \\
Mengkumunikasikan & 2.7 & 3 & 3.22 & 3.77 & Baik \\
Menyimpulkan & 2,15 & 3.25 & 3.77 & 4 & Sangat baik \\
\hline
\end{tabular}

Penelitian dilaksanakan di SMP Negeri 6 Ambon dengan subjek penelitian adalah peserta didik kelas $\mathrm{VII}_{1}$ (tujuh satu) dan objek penelitiannya yakni keterampilan proses yang dimiliki oleh peserta didik kelas $\mathrm{VII}_{1}$. Penelitian dilakukan selama 6 kali pertemuan dalam waktu 3 minggu dalam 3 siklus. Penelitian untuk melihat keterampilan proses peserta didik dilaksanakan sebanyak 6 kali. Materi pembelajaran IPA biologi pada konsep sistem klasifikasi tumbuhan dengan menggunakan kerja ilmiah bertanya. Pengamatan terhadap peserta didik menggunakan Lembar observasi digunakan untuk mengetahui keterampilan proses yang muncul sesuai kegiatan yang dilakukan selama proses pembelajaran berlangsung. Dalam penelitian digunakan observer sebanyak 2 orang. Setiap observer mengobservasi satu kelompok, mereka melakukan penilaian keterampilan proses sains menggunakan instrumen berupa lembar pengamatan atau lembar observasi dengan daftar cek (check list) dan skala penilaian (rating scale) yang terdapat dalam lembar observasi.

Bedasarkan hasil refleksi pada setiap siklus ternyata pada kemampuan siswa dalam mengamati mengalami peningkatan. Pada aspek ini siswa Mengamati bagian tumbuhan secara terampil dan tepat sesuai tujuan dan cirri khusus. Siswa harus ditopang oleh guru melalui meningkatkan kemampuan bertanya. Ketika seorang guru mengajar, pertanyaan merupakan alat untuk merencanakan, mengajar, berpikir, dan belajar. Apakah yang anda ketahui tentang pemakaian pertanyaan di dalam kelas dan kemampuan bertanya anda? Bagi guru, memakai pertanyaan dapat terjadi secara spontan dan sudah menjadi kebiasaan, serta mungkin untuk memotivasi berpikir siswa pada saat siswa melakukan keterampilan mengamati. Penelitian menunjukan bahwa guru tidak menyadari bahwa peningkatan mutu pertanyaan mereka dapat menghasilkan peningkatan pembelajaran pada siswanya. Dalam proses sains, pertanyaan siswa berperan penting dalam pembelajaran mereka. Sebuah pertanyaan dipergunakan untuk keperluan tertentu. Pertanyaan di pakai untuk (a) menemukan apa yang telah diamati apakah ada yang mengetahuinya; (b) memotivasi siswa untuk mengamati lebih teliti; (c) melatih dan praktikan kemampuan bertanya pada diri siswa setelah mengamati; dan (d) membantu siswa untuk berpikir runtut; serta mengembangkan kemampuan berpikir terhadap apayang diamatinya.

Pada aspek keterampilan mengukur siswa diberikan kesempatan untuk mengdiskrpsikan hasil pengukuran tumbuhan sesuai dengan kretifitas siswa. guru perlu memaknai arti sebuah pertanyaan. Hasil penilitian menunjukan bahwa guru memakai lebih banyak dari pada alat bantu mengajar lainnya. Sebuah 
pertanyaan adalah kalimat interogatif (Kalimat Tanya) yang membutuhkan jawaban. Sebuah pertanyaan dinyatakan dalam bahasa yang sederhana, jelas, langsung, yang dapat dimengerti oleh siswa. Sebuah pertanyaan yang baik merangsang pemikiran dan sebaiknya disesuaikan dengan umur, kemampuan, dan minat siswa. Guru memberikan pertanyaan tentang perbedaan hasil pengukuran dari beberapa ukuran daun tumbuhan, mengapa ada perbedaan. Siswa dalam memberikan penjelasan terhadap kemampuan mengukur sesuai dengan pertanyaan guru mencapai hasil sangat baik.

Aspek klasifikasi dalam ketrampilan proses sains pada konsep sistematika tumbuhan merupakan aspek yang cukup sulit tetapi siswa mampu mencapai klasifikasi sangat baik. Istilah baru, mengetahui ciri dan tuntutan mata pelajaran lainnya mengakibatnya siswa memiliki beban kognitif tinggi atau memori kerja yang disimpan melebihi batas yang dimilikinya. Pembelajaran klasifikasi tumbuhan atau mengelompokkan tumbuhan juga dapat mengakibatkan beban kognitif bagi para siswa karena memerlukan kemampuan yang kompleks yaitu konten dan konteksnya. Pada aspek ini guru pertanyaan-pertanyaan yang sifatnya mengarahkan siswa sehingga pertanyaan-pertanyaan itu menuntun siswa untuk mampu melakukan pengelompokan tumbuhan berdasarkan cirri-ciri tumbuhan. Diharapkan guru dapat melakukan pemakaian pertanyaan yang bervarisi, tetapi kenyataannya, pertanyaan guru biasanya meminta jawaban factual dan pemikiran tingkat rendah. Bedasarkan hasil penelitian oleh para ahli bahwa, menggunakan pertanyaan tingkat pengetahuan dan pemahaman meliputi sekitar $70 \%$ diseluruh pertanyaan yang diajukan guru, sedangkan pertanyaan-pertanyaan yang membutuhkan pemikiran penerapan, analisis, sistesis, atau evaluasi tidak banyak dipakai (Wood, \& Stevens, 1988 dalam Martin, dkk. 1997).

Aspek memprediksi, siswa mecapai katagori baik. Yang diharapkan dari aspek ini adalah Siswa memahami dengan benar fakta hasil identifikasi tumbuhan dan membuat prediksi. Hal yang dilakukan oleh guru adalah harus memahami apa dampak pertanyaan terhadap siswa. Pertanyaan yang dipilih digunakan guru agar dapat mempengaruhi siswa dalam tiga aspek yaitu, cara berpikir, dan memberikan dugaan sementara terhadap hasil pengamatan siswa terhadap tumbuhan. Sikap yang mempengaruhi agar siswa berpartisipasi, berpikir, dan memberikan dugaan semnetara. Setiap siswa akan mengemukakan dugaan-dugaannya sesuai dengan apa yang diamatinya. Siswa diberikan kesempatan untuk menemukan dan membuktikan dugaan-duagaan tersebut. Dari hasil penelitiannya, William Wilen, (1986 dalam Martin, 1997) menyimpulkan bahwa pertanyaan guru berperan penting dalam membentuk sikap, pemikiran, dan keberhasilan belajar siswanya. Lebih lanjut Wilen (1986) menulis bahwa "Siswa akan bersikap positif terhadap pertanyaan-pertanyaan tingkat tinggi, apabila kita mengharapkan pendekatan intruksional seperti inkuiri memberikan hasil yang efektif.

Kemampuan siswa dalam mengkomunikasikan cirri-ciri tumbuhan sesuai dengan tingkatan takson mencapai katagori baik. Kemampuan yang diharapkan dari siswa pada aspek ini adalah mengkomunikasikan dengan cara pengelompokkan cirri tumbuhan dilanjutkan sampai dihasilkan kelompok yang tidak dapat dibagi-bagi lagi ke dalam kelompok yang lebih kecil, sehingga akan ditemukan nama dari tumbuhan tersebut. Pertanyaan yang dikemukakan guru sangat mempengaruhi cara berpikir siswa. Pada aspek ini siswa mengalami kesulitan dalam menyusun kalimat-kalimat untuk membentuk sebuah pernyataan untuk menempatkan cirri tumbuhan sesuai takson yang benar. Siswa Guru yang mengharapkan siswa untuk berpikir pada tingkat tertentu, menyusun atau memakai pertanyaan, mecari literature yang sesuai yang diharapkan guru. Pertanyaan dari siswa merupakan indicator tingkat pemikiran siswa dan akan dilakukan karena pengarus pertanyaan guru walaupun masih cukup sulit dan lambat tetapi pada akhirnya siswa mampu mengkomunikasikan cirri tumbuhan sesuai dengan tingkat taksonnya.

Pada aspke ketrampilan proses menyimpulkan siswa mencapai kategori sangat baik. Kemampuan yang diharapkan terbentuk pada siswa adalah memahami konsep dan menyimpulkan untuk 
mengaplikasi pada konsep lain. Kemampuan siswa menyimpulkan merupakan aspek yang cukup penting karena mempunyai tingkat kesulitan yang cukup tinggi. Ketika siswa mampu menyimpulkan dapat memberikan gambaran bahwa siswa mampu berpikir dan menguasai serta mengkomunikasikan apa yang dipelajarinya secara menyeluruh. Guru meng Silberman, (2009) menyarankan bahwa strategi yang efektif adalah mengajukan pertanyaan, tunggu, meminta siswa menjawab, tunggu, kemudian memberikan reaksi yang menandai/tepat atau menanyakan ke siswa lain. Fungsi pembelajaran sains adalah membentuk siswa untuk meningkatkan kemampuan berpikirnya. Untuk tujuan tersebut guru perlu memberikan kemungkinan berkomunikasi dengan siswa dan antara siswa dengan siswa. Salah satu cara berkomunikasi adalah dengan mengajukan pertanyaan.

\section{Data Temuan dan Rekomendasi Hasil Refleeksi Terhadap Pelaksanaan Pembelajaran Tiap Siklus}

Berdasarkan analisis hasil penilaian aktivitas guru dan siswa hasil refleeksi terhadap pelaksanaan pembelajaran tiap siklus ada beberapa hal yang harus diperhatikan pada pelaksanaan pembelajaran yaitu:

1. Guru harus lebih meningkatkan kemampuan bertanya;

2. Guru perlu memaknai arti sebuah pertanyaan;

3. Guru harus mengavaluasi jenis-jenis pertanyaan apakah yang dipakai guru dan jawaban mana yang dibutuhkan siswa

4. Guru harus memahami apa dampak pertanyaan terhadap siswa.

5. Guru perlu memberikan kesempatan berpikir kepada anak untuk menjawab pertanyaan;

6. Guru perlu memperhatikan hubungan pertanyaan guru dan jawaban siswa;

7. Guru perlu menggunakan pertanyaan untuk melibatkan semua siswa;

8. Guru harus menggunakan ramburambu pertanyaan yang lebih efektif;

9. Guru harus membiasakan menggunakan atau mengulangi pertanyaan siswa dalam pembelajaran.
10. Guru harus mengajukan pertanyaan sederhana, sepadat mungkin, dan secara langsung.

11. Guru mengajukan pertanyaan sebelum memilih siapa yang harus menjawab.

12. Guru menghindari jawaban siswa yang ngaur, tetapi usahakan memakai ide-ide siswa

13. sebanyak mungkin.

14. Guru memberikan kesempatan berpikir setelah bertanya.

15. Guru perlu memakai waktu tunggu sebagai pemberian kesempatan berpikir setelah bertanya.

16. Guru perlu mendengar dengan baik respon dari siswa.

17. Guru perlu menggunakan lebih banyak pertanyaan untuk menghasilkan pertentangan

18. konseptual.

19. Guru perlu membatasi bicara dan banyak bertanya, tetapi usahakan pertanyaan guru untuk

20. dapat diperhitungkan.

21. Guru perlu memakai pertanyaan untuk mengahasilkan respon yang lengkap dan lebih

22. majemuk.

23. Guru perlu mengajukan berbagai tipe pertanyaan untuk memberikan semangat kepada

24. seluruh siswa.

\section{KESIMPULAN DAN SARAN}

Berdasarkan hasil penelitian tindakan kelas dan pembahasan yang telah diuraikan di atas, dapat ditarik beberapa kesimpulan, yaitu:

1. Penerapkan konsep dan prinsip dalam biologi melalui kerja ilmiah bertanya dapat meningkatkan kinerja guru

2. Penerapan kerja ilmiah bertanya menigkatkan hasil belajar siswa

3. Penerapan kerja ilmiah bertanya meningkatkan motivasi belajar siswa

4. Penerapan kerja ilmiah bertanya menciptakan iklim belajar yang kondusif

5. Penerapan kerja ilmiah bertanya meningkatkan ketrampilan proses sains siswa

Bedasarkan temuan dan kesimpulan di atas ada beberapa saran yang harus diperhatikan dalam pelaksanaan pembelajaran di kelas yaitu guru harus lebih 
banyak berlatih menyusun pertanyaan untuk mengungkapkan fakta, menyusun pertanyaan tentang prosedur, menyusun pertanyaan tentang alasan penggunaan alat atau bahan tertentu, dan menyusun pertanyaan untuk merancang suatu kegiatan ilmiah.

\section{DAFTAR PUSTAKA}

Arikunto, S. 2011. Penelitian Tindakan Kelas. Jakarta: Bumi Aksara

Bachtiar, R.W. 2015. Pengembangan Model Pembelajaran Problem Mapping Concept Untuk Meningkatkan Keterampilan Proses Sains. e-journal. ikippgrimadiun. ac.id/index. php/JPFK. Vol. 1. No. 2, September 2015, Hal 90 98.

Cahyaningratri, D.P. 2012. Pendekatan CTL Dengan Metode Problem Solving Untuk Meningkat kan Kualitas Pembelajaran Biologi Siswa Kelas VIIIC SMP Negeri 27 Surakarta Tahun Pelajaran 2011/2012. (Skripsi). Surakarta: Program Studi Pendidikan Biologi FKIP UNS.

Dimyati dan Mujiono. 2009. Belajar dan Pembelajaran. Jakarta: Rineka Cipta

Departemen Pendidikan Nasional. 2003a. Kurikulum Berbasis Kompetensi Kebijakan Umum (Buku 1-A). Departemen Pendidikan Nasional; Jakarta

Shinta Dewi, 2008. Keterampilan Proses Sains, Penerbit Tirta Emas Publishing, Bandung,

Erni, S. 2009. Studi tentang Kompetensi Pedagogik dan Profesional bagi Guru Geografi di SMA Negeri di Kabupaten Pati. Jurnal Geografi FIS. Volume 06 nomor 02. Semarang: UNNES. Hamalik, O.2011. Psikologi Pendidikan. Jakarta: Depdikbud

Fauziah, R., Abdullah, A.G., \& Hakim, D.L. (2013). Pembelajaran saintifik elektronika dasar berorientasi pembelajaran berbasis masalah. Invotec 9(2): 165-178.

Hamdu, Ghullam dan Agustina, Lisa. 2011. Pengaruh Motivasi Belajar Siswa Terhadap Prestasi Belajar IPA di Sekolah Dasar (Studi Kasus Terhadap Siswa Kelas IV SDN Tarumanegara Kecamatan Tawang Kota Tasik
Malaya). Jurnal penelitianpendidikan, (online), Vol. 12 No. 1 (http:/jurnal.upi.edu/file/8-

Ghullam_Hamdu.pdf, diakses 20 Desember 2012).

Irawan, O.G.2014. Pengaruh Iklim Belajar yang Kondusif Terhadap Hasil Belajar Siwa Mata Pelajaran IPS Terpadu di SMP. Arikel IImiah. Universitas TanjungPura Pontianak

Ma'mur, Jamal Asmani. 2009. 7 Kompetensi Guru Menyenangkan Dan Professional. Yogyakarta: Power Books.

Martin, Ralph; Sexton, Colleen; Wagner, Kay; dan Gerlovich, Jack. 1997. Teaching Science for All Children. Second Edition. Boston: Allyn and Bacon.

Mulyasa, E. 2006. Implementyasi Kurikulum Berbasis Kompetensi. Bandung. Remaja Rosda Karya

Pertiwi, Dyah Ayu B. 2013. "Improving Students Scientific Attitude Towards Experiment Method with Inquiri approach on the Rmochemistry subject in eleventh grade science students of SMA N 3 Sanggau". Journal Pendidikan. Pontianak: FKIP Untan.

Rustaman, Nuryani. (2005). Strategi Belajar Mengajar Biologi. Malang: UM Press

Salinan Peraturan Menteri Pendidikan Dan Kebudayaan Republik Indonesia No 81 A Tahun 2013 Lampiran IV Tentang Implementasi Kurikulum Pedoman Umum Pembelajaran.

Sardiman. 2011. Interaksi dan Motivasi Belajar Mengajar. Jakarta: Rajawali Pers.

Saud, U.S. 2009. Pengembangan Profesi Guru. Bandung: Alfabeta

Silberman, M. (2009). Active Learning 101 Strategi Pembelajaran Aktif. Yogyakarta: Pustakan Insan Madani.

Suparmi. 2012. Penerapan Pendekatan CTL Dengan Model Problem Posing Untuk Meningkatkan Kualitas Pembelajaran Biologi Siswa Kelas X.2 SMA Negeri 2 Karanganyar Tahun Pelajaran 2011/2012. (Skripsi). Surakarta: Program Studi Pendidikan Biologi FKIP UNS. 
Susanto, A. (2013). Teori Belajar dan Pembelajaran di Sekolah Dasar. Jakarta: Kencana Prenada Media Group.

Susilo, H. 2003. Pembelajaran Kontekstual untuk meningkatkan Pemahaman Siswa. Makalah disampaikan pada Seminar Pembelajaran dengan Filosofi Konstruktivisme. Jombang 22 September.

Syah, Muhibbin. 2010. Psikologo Pendidikan. Jakarta: Remaja Rosdakarya.

Trianto. (2007). Model Pembelajaran Terpadu dalam Teori dan Praktek. Jakarta: Kencana Pre- nada Media Group.

Uno, H.B. 2010. Model Pembelajaran Menciptakan Proses Belajar Mengajar Yang Kreatif dan Efektif. Jakarta: Bumi Aksara.

Utami, A. 2012. "Pengaruh Strategi Pembelajaran Guided Inquiry Terhadap Keterampilan Proses Sains ditinjau dari Gaya Belajar siswa kelas VIII SMP Negeri 1 Jaten Tahun Pelajaran 2011/2012". Skripsi. Surakarta: UNS.
Wibowo. 2006. Profil Pertanyaan Guru dan Siswa dalam Pembelajaran Sains. Sumatera Barat: Pendidikan Sains STKIP PGRI.

Widodo, Joko dan Ellyana, Novita Eka. 2011. Pengaruh Pengembangan Motivasi dan penggunaan Fasilitas Belajar di Sekolah Terhadap Prestasi Belajar Pada Mata Pelajaran Ekonomi. Jurnal Pendidikan Ekonomi, vol 5. No. 2. Jember: Universitas Negeri Jember

Zahroul, Chumi dan Dwi A, Dhiyah. 2010. Pengaruh Penyediaan Fasilitas Belajar Anak di Rumah dan Motivasi Belajar Terhadap Prestasi Belajar (Studi Kasus Pada Siswa Kelas VII Semester Ganjil SMP Negeri 1 Yosowilangun Tahun Ajaran 2008/2009). Jurnal Pendidikan Ekonomi, Edisi 5, vol. 1. Jember: Universitas Negeri Jember

Widodo. 2005. Pedoman Pendidikan dan Pengajaran. Surabaya: Usaha Nasional. Wibowo. 2006. Profil Pertanyaan Guru dan Siswa dalam Pembelajaran Sains. Sumatera Barat: Pendidikan Sains STKIP PGRI. 